\title{
(U-Th)/He thermochronometric mapping across the northeast Japan Arc: towards understanding mountain building in an island-arc setting
}

\author{
Shoma Fukuda ${ }^{* *}$, Shigeru Sueoka ${ }^{2}$, Barry P. Kohn ${ }^{3}$ and Takahiro Tagami ${ }^{1}$
}

\begin{abstract}
Topographic relief in arc-trench systems is thought to be formed by plate subduction; however, few quantitative investigations have so far been reported, with respect to the related mountain building process. This study applies apatite and zircon ( $\mathrm{U}-\mathrm{Th}$ )/He thermochronometry (AHe, ZHe, respectively) to Cretaceous granite rocks in the north part of the northeast (NE) Japan Arc to reveal its cooling/denudation history. Weighted mean AHe ages ranging from 88.6 to $0.9 \mathrm{Ma}$ and ZHe ages from 83.9 to $7.4 \mathrm{Ma}$ were determined for 10 rock samples. Using the AHe data, denudation rates were obtained for each sample. On the fore-arc side, denudation rates of $<0.05 \mathrm{~mm} /$ year were calculated, indicating a slow denudation process since the Paleogene. However, in the Ou Backbone Range and on the back-arc side, denudation rates at $>0.1-1.0 \mathrm{~mm} /$ year were computed, probably reflecting a recent uplift event since $\sim 3-2 \mathrm{Ma}$. These data indicate a clear contrast in thermal and denudation histories between the tectonic units in this study area, similar to that previously reported from the southern part of NE Japan Arc. A comparison of the thermal/denudation histories between the $\mathrm{N}$ - and S- traverses, revealed the arc-parallel trend, the uplift model of the volcanic arc, and some minor variations of thermal/denudation histories in each tectonic unit. This study offers some further insights into the understanding of tectonic processes in an island-arc setting.
\end{abstract}

Keywords: Low-temperature thermochronology, Arc-trench system, Northeast Japan Arc, (U-Th)/He thermochronometry, Thermal/denudation histories

\section{Introduction}

Arc-trench systems, resulting from plate subduction processes, form mobile belts, characterized by orogenesis, volcanism, and earthquakes. Early studies of arc-trench systems were largely based on geomorphology and structural geological studies (e.g., Dickinson and Seely 1979; Uyeda 1982, 1983).

Mountain building processes at collision zones, e.g., the European Alps and Himalayas, have been investigated

\footnotetext{
*Correspondence: s-fukuda@kueps.kyoto-u.ac.jp

${ }^{1}$ Department of Geology and Mineralogy, Division of Earth and Planetary Sciences, Graduate School of Science, Kyoto University, Kyoto 606-8502, Japan

Full list of author information is available at the end of the article
}

quantitatively on the basis of thermochronologic methods (e.g., Wagner et al. 1977; Vernon et al. 2008; Burbank et al. 1996; Blythe et al. 2007). However, similar studies in island-arc settings are somewhat limited (see compilation in Herman et al. 2013), because their inland topography is often too young and/or of too low relief to be investigated by these methods. As a result of recent developments in low-temperature thermochronology, such as improving thermal inverse modeling, based in part on apatite fission track (AFT) data (e.g., Ketcham 2005; Gallagher 2012) and the resurgence and modern understanding of the (U-Th)/He system (e.g., Reiners and Brandon 2006; Ault et al. 2019), thermochronology has 
been successfully applied to mountainous terrain even in island-arc settings (Sueoka et al. 2016).

We have previously attempted to reconstruct mountain building processes in the northeast (NE) Japan Arc using low-temperature thermochronology (Sueoka et al. 2017; Fukuda et al. 2019). Sueoka et al. (2017) conducted apatite and zircon ( $\mathrm{U}-\mathrm{Th}$ )/ $\mathrm{He}$ (AHe and $\mathrm{ZHe}$, respectively) thermochronology study across the southern NE Japan Arc, Abukuma Mountains on the fore-arc, the $\mathrm{Ou}$ Backbone Range (OBR) and the Iide and Asahi Mountains on the back-arc (hereinafter, the S-traverse). Fukuda et al. (2019) conducted thermal inverse modeling based on the AFT method using the same samples of Sueoka et al. (2017). These studies showed contrasting ages and denudation rates between the fore-arc side, volcanic front, and back-arc side in the S-traverse (Fig. 1). Namely, older ages and slower denudation rates on the fore-arc side, and younger ages and faster denudation rates in the OBR and on the back-arc side. This contrast probably reflects the spatial variation of uplift/denudation rates under the recent strong compressive stress field since the Quaternary.

In this paper, we investigate the thermal/denudation histories in the northern NE Japan Arc, i.e., Kitakami Mountains on the fore-arc side, the OBR, and Taihe and Shirakami Mountains on the back-arc side (hereinafter collectively referred to as the N-traverse see Fig. 1). Previous thermochronometric research reported from the S-traverse offered some geological insights; however, it left open the question as to whether the implications were relevant across the entire NE Japan Arc. Therefore, in this work, we report $\mathrm{AHe}$ and $\mathrm{ZHe}$ thermochronometric data from across the $\mathrm{N}$-traverse and compare the thermal/denudation histories derived with those from the S-traverse.

\section{Geomorphology and geology}

The basic components of an island arc have been described as comprising; a trench, fore-arc, volcanic front, and back-arc basin (e.g., Dickinson and Seely 1979). As such, the NE Japan Arc can be classified as a typical island arc because with respect to the cross-arc direction, its inland topographies appear in such a geomorphic arrangement (e.g., Ota et al. 2010) (see cross section in Fig. 1). In this paper, following the definition of Koike et al. (2005), we divide the NE Japan Arc into three tectonic units: the fore-arc side, the OBR, and the backarc side, with the OBR regarded as the volcanic front.

In the northern NE Japan Arc, clear geological differences are observed between the fore-arc side and the back-arc side of the OBR. Cretaceous granitic rocks at approximately 120-100 Ma (e.g., Yokoyama et al. 2016) are widely exposed only in the Kitakami Mountains on the fore-arc side. In contrast, green tuffaceous rocks and volcanic ejecta formed around and after the Miocene, cover most of the basement rocks in the OBR and on the back-arc side. More than 30 Quaternary volcanoes are distributed around the OBR and the back-arc side; whereas, no Quaternary volcanism has been reported from the fore-arc side (Fig. 1).

The tectonic history of NE Japan has been investigated using various methods such as structural geology, stratigraphy, and volcanology (e.g., Sato 1994; Nakajima et al. 2006; Nakajima 2013; Yoshida et al. 2013). Prior to $\sim 21 \mathrm{Ma}$, the NE Japan Arc was located at the edge of the Asian continent. Between $\sim 21$ and $13.5 \mathrm{Ma}$, the opening of the Sea of Japan occurred due to spreading of the back-arc basin (e.g., Otofuji et al. 1985; Jolivet et al. 1994), forming the NE Japan Arc. Following its formation as an island arc, a compressional stress field developed and has been dominant in the NE Japan Arc since $\sim 8 \mathrm{Ma}$ (e.g., Nakajima 2013). From $\sim 3$ to 2 Ma to present, the inland topographic relief was formed (Yonekura et al. 2001) under an intense compressional stress field derived from subduction of the Pacific and Philippine Sea plates (Takahashi 2006, 2017). This E-W compressive stress regime reactivated ancient normal faults formed during the opening of the Sea of Japan as reverse faults (Sato 1994; Okamura et al. 1995; Okada and Ikeda 2012). Therefore, major topographic structures (e.g., faults, mountains) are generally distributed in an $\mathrm{N}-\mathrm{S}$ direction along the NE Japan Arc.

\section{Samples and analytical methods \\ Samples}

We collected 20 Cretaceous granite samples along an $\mathrm{N}$-traverse to apply AHe and ZHe dating (Fig. 1), and obtained $\mathrm{AHe} / \mathrm{ZHe}$ data for 10 samples. To avoid possible reheating from recent volcanisms, sample localities were located $>10 \mathrm{~km}$ away from Quaternary volcano centers and high-temperature zones. Geothermal gradients measured in boreholes generally drop to background levels at $\sim 10-20 \mathrm{~km}$ from Quaternary volcanic centers in Japan (Umeda et al. 1999). Based on this evidence, any thermal effects on our data from Quaternary volcanoes are disregarded for discussion in this work.

\section{(U-Th)/He thermochronometry}

Low-temperature thermochronology is a powerful tool to reveal thermal history. In particular, $\mathrm{AHe}$ and $\mathrm{ZHe}$ thermochronology data, because of the range of their temperature sensitivity, are useful for reconstructing cooling and denudation histories in the shallow crust (e.g., Reiners and Brandon 2006). In general, the typical closure temperatures for $\mathrm{AHe}$ thermochronometer are in the range $50-100{ }^{\circ} \mathrm{C}$ (Ault et al. 2019), and for $\mathrm{ZHe}$ 

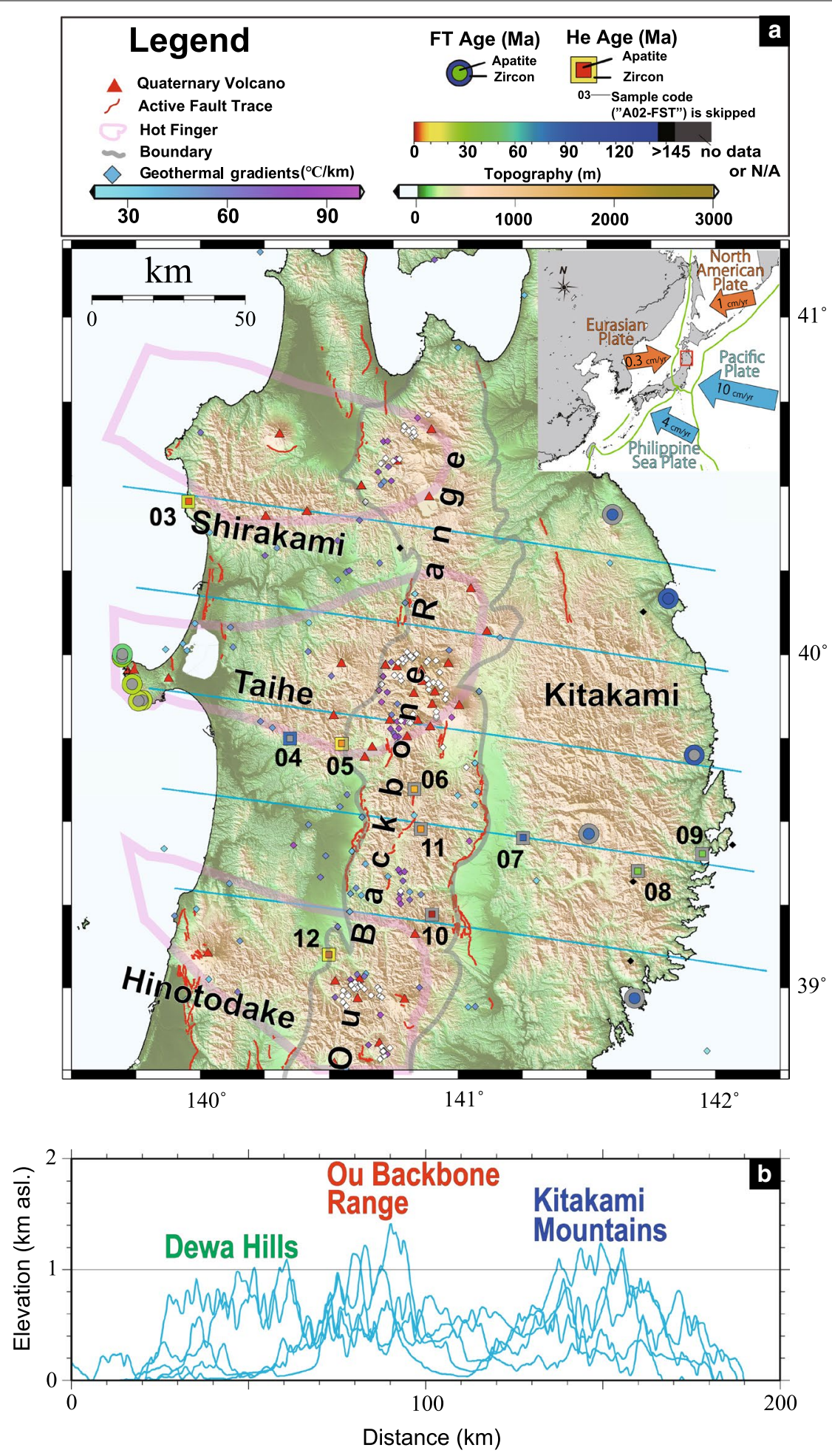

Fig. 1 a Index map of the study area of the N-traverse. Numbered localities are our sampling sites. (U-Th)/He ages obtained in this study are also shown. Quaternary volcanoes: Committee for Catalog of Quaternary Volcanoes in Japan (1999); Active fault traces: Nakata and Imaizumi (2002); Hot Fingers: Tamura et al. (2002); Geothermal gradients: Tanaka et al. (2004); FT age: ages without sample codes indicating data from previous studies: Ganzawa (1987) on the back-arc side, and Goto (2001) on the fore-arc side; Boundaries: the lines showing the eastern and western limits of the OBR, defined by Koike et al. (2005). b Geomorphic cross section of study area. The cross sections were drawn along the 5 light blue lines in Figure (a). These figures were drawn using Generic Mapping Tools (GMT; Wessel and Smith 1991) and 50-m mesh digital elevation model (DEM) of the Geospatial Information Authority of Japan (GSI) 
is $100-200{ }^{\circ} \mathrm{C}$ (Guenthner et al. 2013; Ault et al. 2019); therefore, thermal histories from depths of $\sim 2-7 \mathrm{~km}$ can be reconstructed under common geothermal gradients $\left(\sim 30{ }^{\circ} \mathrm{C} / \mathrm{km}\right)$. However, He diffusivity may vary as a result of various factors, such as, the grain size and the cooling rate (e.g., Reiners and Brandon 2006; Ault et al. 2019), and also the degree of $\alpha$-radiation damage (e.g., Shuster et al. 2006; Guenthner et al. 2013; Cherniak 2019). The variation of $\mathrm{He}$ diffusivity in individual grain impacts on the nominal closure temperature and thus their ages, which introduces complexities in the interpretation of such ages for reconstructing thermal histories. Hence, an evaluation of the reproducibility of grain ages is essential for interpreting He thermochronometric data.

\section{Experimental procedures for He content measurement}

The mineral separation of apatite and zircon was carried out at Kyoto Fission-Track Co., Ltd., using conventional methods. Samples were crushed into small pieces manually with a stainless mortar and pestle, and also using a rod mill. This was followed by magnetic separation, performed using a neodymium magnet (NEOMAX) for removing magnetic minerals. The target minerals were concentrated by density separation using sodium phosphate tungstate (SPT: $3.07 \mathrm{~g} / \mathrm{cm}^{3}$ : Danhara et al. 1992) and diiodomethane $\left(\mathrm{CH}_{2} \mathrm{I}_{2}: 3.33 \mathrm{~g} / \mathrm{cm}^{3}\right)$ as the heavy liquid.

(U-Th)/He analyses were conducted at the University of Melbourne. Three or four suitable grains were handpicked under a binocular microscope using the following criteria: grain width of 75 up to $200 \mu \mathrm{m}$, transparent and authigenic shapes, and no visible inclusions. Grain geometries were recorded using ImageJ software because these parameters are used to calculate the $F_{T}$ correction (Farley et al. 1996) for calibrating the alphaejection in each crystal. After measuring grain sizes, one or a few grains of apatite and a single grain of zircon were put into small acid-treated platinum capsules.

Experimental protocols of $\mathrm{He}$ content measurement were based on House et al. (2000) using a laser extraction system. Single grains were outgassed for ${ }^{4} \mathrm{He}$ under vacuum using a laser set on a wavelength of $820 \mathrm{~nm}$ with fiber-optic coupling to the sample chamber. Conditions of laser ablation heating were $\sim 900{ }^{\circ} \mathrm{C}$ for $5 \mathrm{~min}$ for apatite, and for $\sim 1300{ }^{\circ} \mathrm{C}$ for $20 \mathrm{~min}$ for zircon. A hot blank measurement was also conducted to ensure total degassing of ${ }^{4} \mathrm{He}$ after each gas extraction. He concentrations were determined using isotope dilution against a pure ${ }^{3} \mathrm{He}$ spike, calibrated against an independent ${ }^{4} \mathrm{He}$ standard. In cases where ${ }^{4} \mathrm{He}$ content of a single grain was too low, aliquots of multiple grains were analyzed for accumulating a detectable content.
Second, dissolving the degassed grains and analyzing parent isotopes were performed after all Pt packets were removed from the sample stage. For dissolving apatite grains, whole Pt capsules were immersed into $\mathrm{HNO}_{3}$ to measure ${ }^{238} \mathrm{U},{ }^{235} \mathrm{U},{ }^{232} \mathrm{Th}$, and ${ }^{147} \mathrm{Sm}$ concentrations using solution ICP-MS. While in zircon, degassed grains were removed from their Pt capsules and transferred to where they were spiked with ${ }^{233} \mathrm{U}$ and ${ }^{229} \mathrm{Th}$ and digested in small volumes $(0.3-0.5 \mathrm{ml})$ at $240{ }^{\circ} \mathrm{C}$ for $40 \mathrm{~h}$ in HF. Standard solutions containing the same spike amounts as samples were treated identically, as were a series of unspiked reagent blanks. A second bombing in $\mathrm{HCl}$ for $24 \mathrm{~h}$ at $200{ }^{\circ} \mathrm{C}$ ensured dissolution of fluoride salts. Zircon solutions were then dried down, dissolved in $\mathrm{HNO}_{3}$ and diluted in $\mathrm{H}_{2} \mathrm{O}$ to $5 \%$ acidity for analysis of ${ }^{238} \mathrm{U},{ }^{235} \mathrm{U}$ and ${ }^{232} \mathrm{Th}$ by solution ICP-Mass Spectrometry. For checking analytical accuracy, we simultaneously measured age standard samples as unknown samples. In this case, we used Durango apatite (McDowell et al. 2005) and Fish Canyon Tuff zircon (Gleadow et al. 2015) as standards.

\section{Dating results}

$\mathrm{AHe}$ and $\mathrm{ZHe}$ dating results are shown in Tables 1 and 2, respectively. All He dating results are also displayed in Fig. 1a. Moreover, as mentioned previously, we also measured Durango apatite and Fish Canyon Tuff zircon as secondary standards, which yielded ages of 32.330.0 Ma, and 29.9-28.1 Ma, respectively (Tables 1 and 2). These results are consistent with reference ages within the $\pm 2 \sigma$ uncertainty level (Durango: $32.1 \pm 1.7(1 \sigma) \mathrm{Ma}$ : McDowell et al. 2005; FCT: $28.01 \pm 0.04(1 \sigma)$ Ma: Phillips and Matchan 2013), which verified the accuracy of measurements in this study.

\section{Reproducibility of grain ages}

To calculate the weighted mean age of samples, more than three intra-sample analyses were used, employing IsoplotR (Vermeesch 2018). We verified whether grain ages within the error range of $\pm 3 \sigma$ were consistent or not with a weighted mean age ranging within $\pm 95 \%$ confidence interval. When single grain ages did not overlap within the weighted mean age of a sample, the grain ages were rejected as outliers and the weighted mean age without such outliers was recalculated.

The accumulation of $\alpha$-radiation damage and other parameters can impact strongly on ${ }^{4} \mathrm{He}$ retention in apatite and zircon; thus, such effects should be taken into account for interpretation of thermochronologic data (see also a review in Ault et al. 2019). Recent studies concerning the effects of radiation damage have also been investigated in the AHe system (e.g., Shuster et al. 


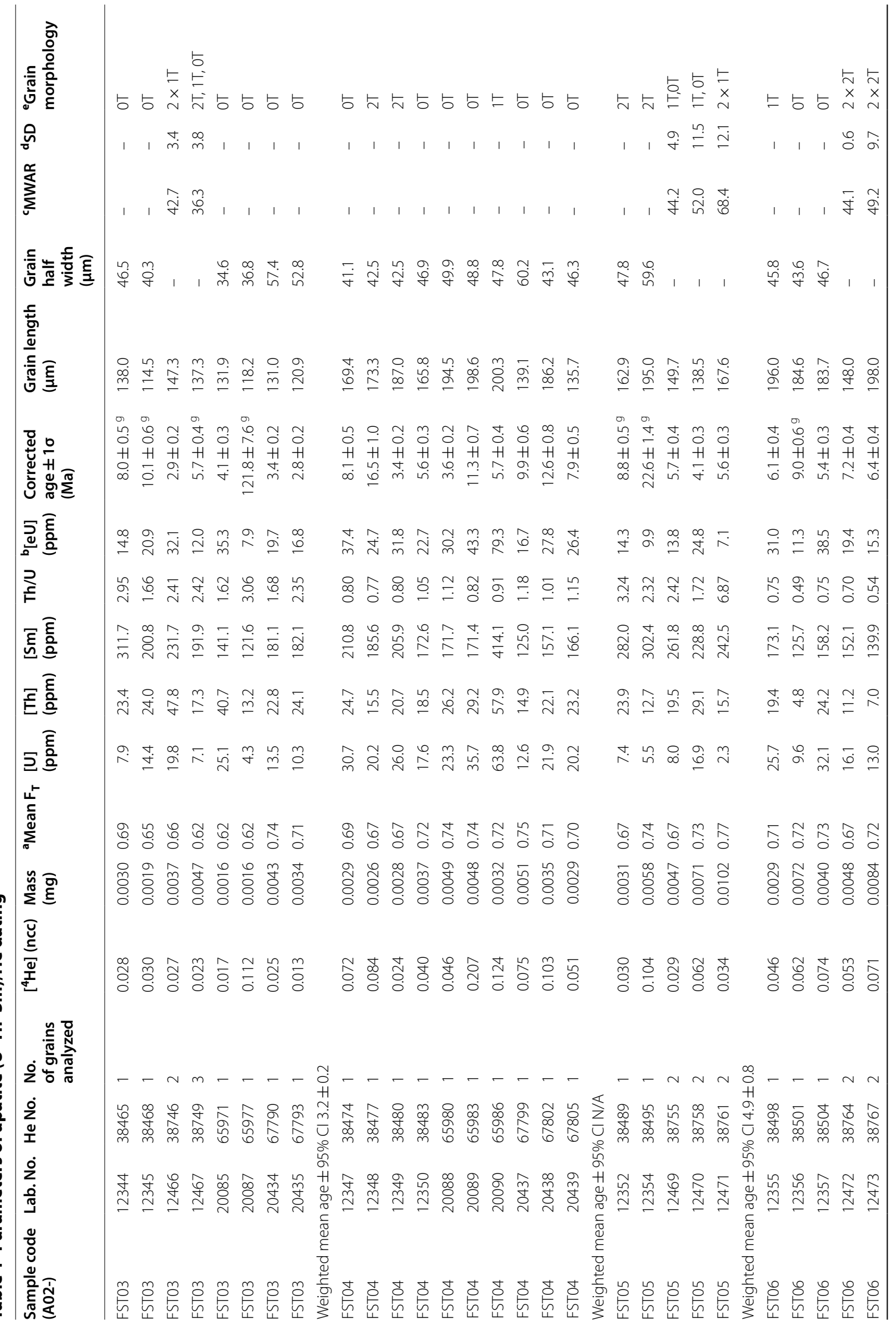




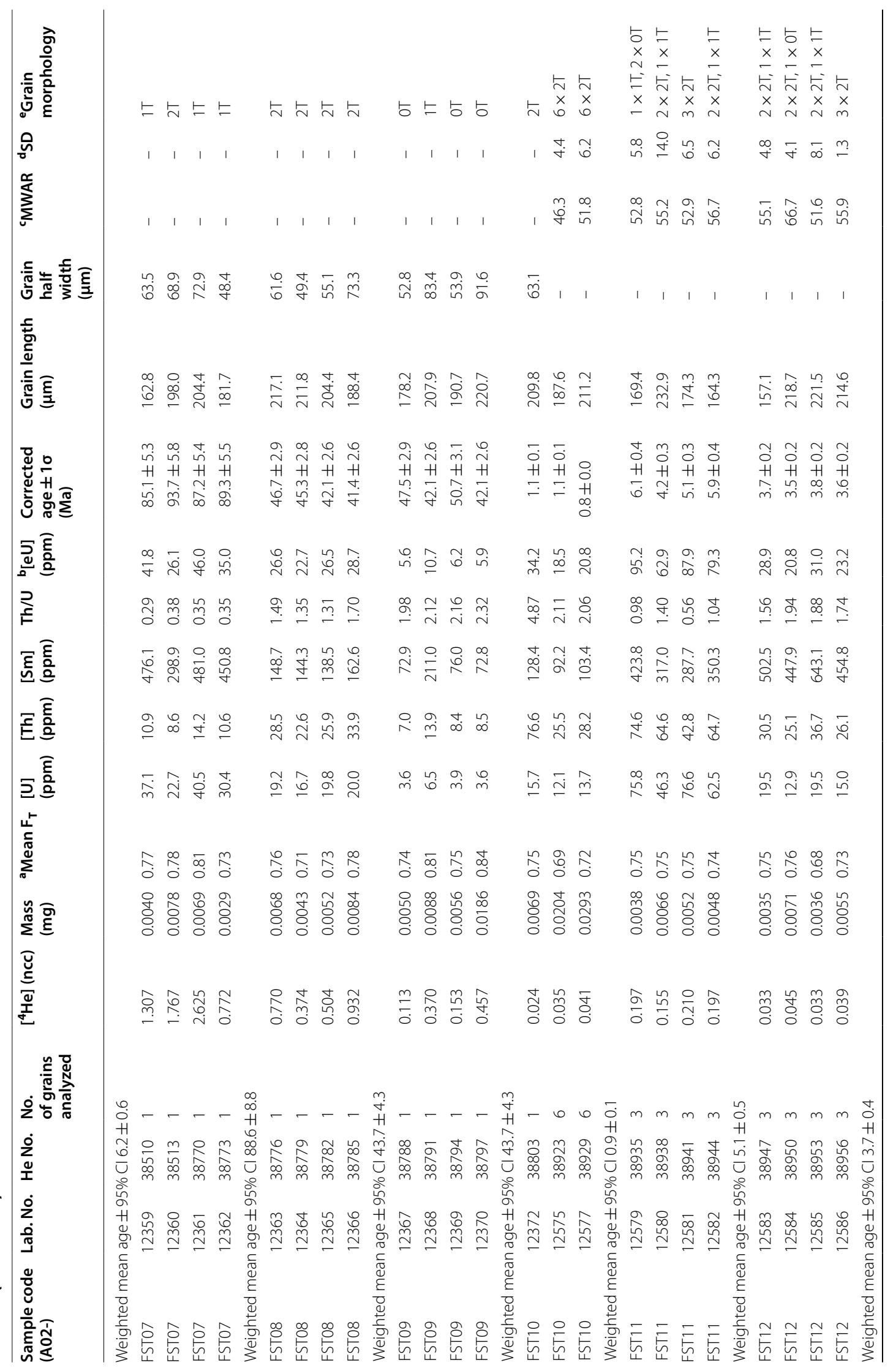




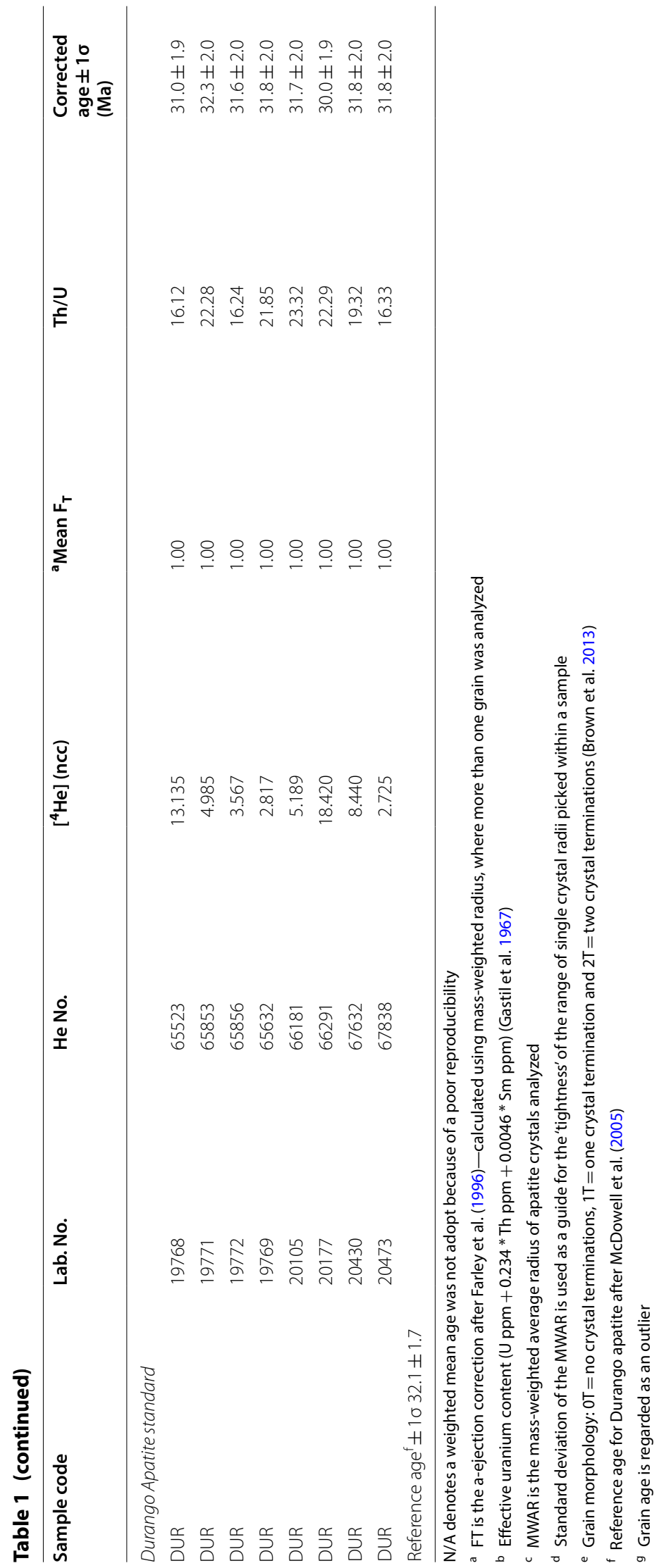




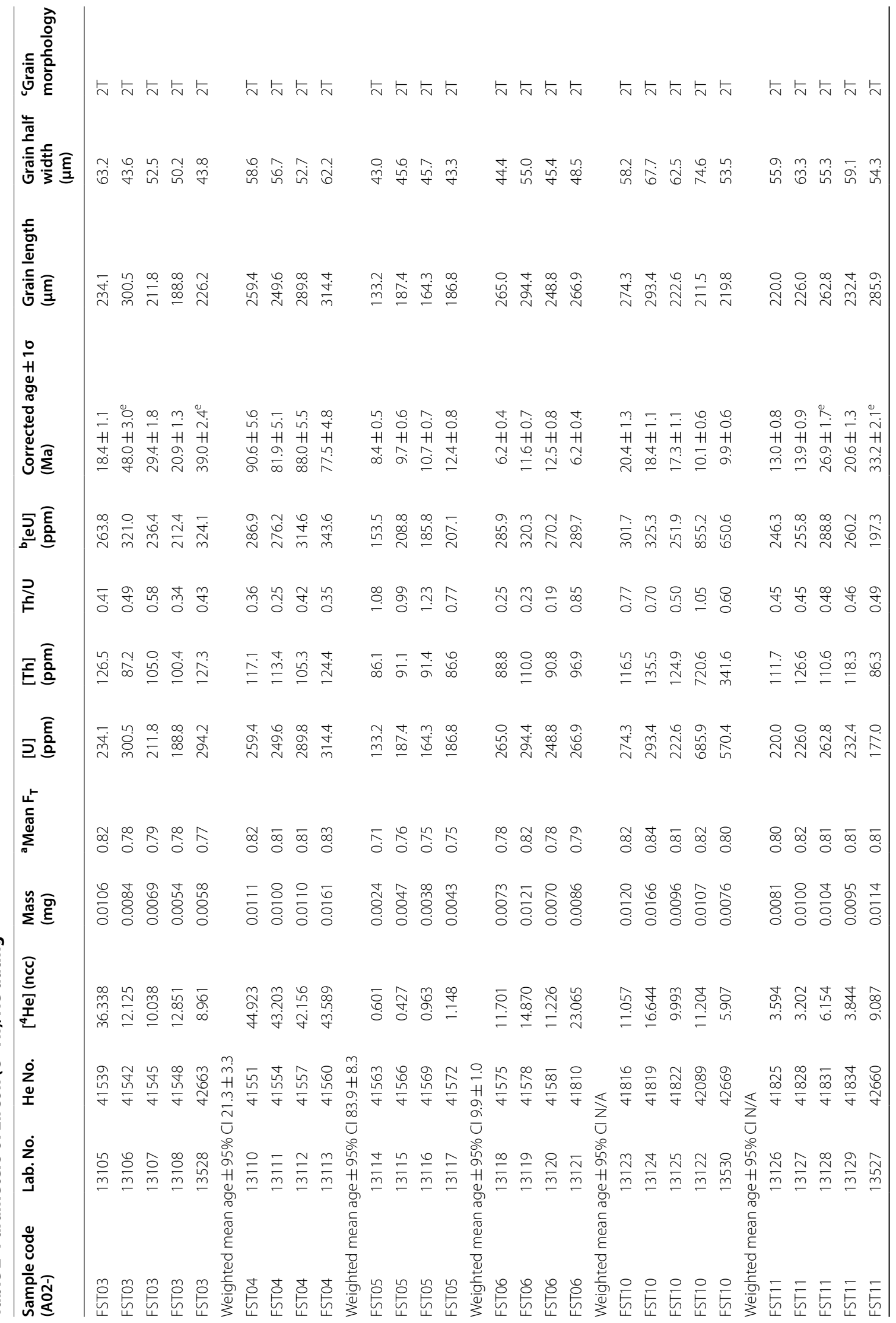




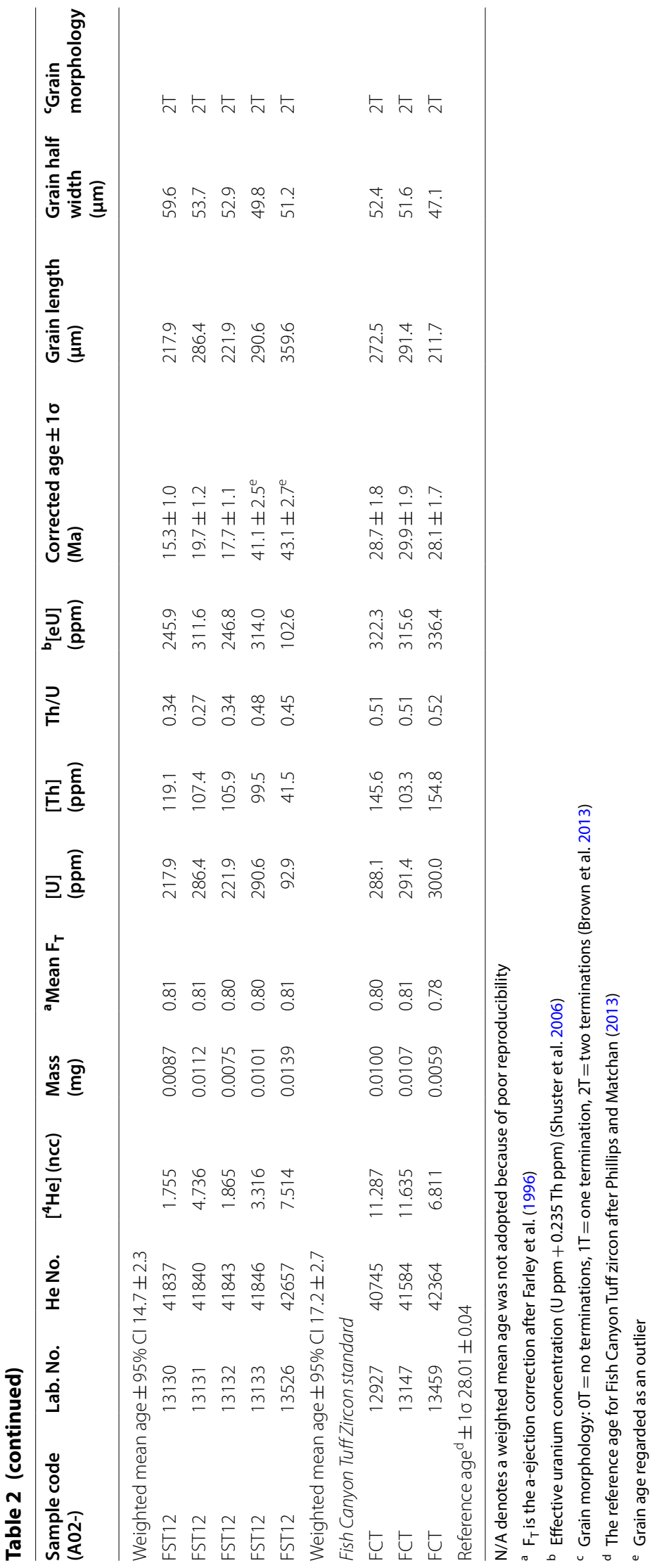


2006; Flowers et al. 2009; Gautheron et al. 2009; Shuster and Farley 2009; Willett et al. 2017; Recanati et al. 2017), and the ZHe system (e.g., Guenthner et al. 2013; Anderson et al. 2017; Johnson et al. 2017; Ginster et al. 2019; Cherniak 2019). However, our samples were expected to have been less affected by radiation damage, because they are Cretaceous granites which yield younger He ages and lower uranium and thorium content than found in similar rock types in most major orogens world-wide. If the radiation damage effect is negligible, then the age obtained can be interpreted as a cooling ages reflecting a thermal history. For verifying the reproducibility of $(\mathrm{U}-\mathrm{Th}) / \mathrm{He}$ grain ages and the effect of possible radiation damage, plots of age versus effective uranium (eU) ppm (a proxy for radiation damage) (Shuster et al. 2006; Flowers et al. 2009) were constructed for each locality (Figs. 2 and 3). If the plot showed a positive or negative correlation within $3 \sigma$, the sample was considered to have a dispersed age, owing to radiation damage, or possibly some other factors (e.g., see Table 3 in Wildman et al. 2016). If grain ages were over-dispersed and did not correlate with eU, we calculated the arithmetic mean ages from all grains including possible outliers even for such poor age reproducibility samples. As an overview of radiation damage accumulation in our samples, eU in apatite reaches $100 \mathrm{ppm}$ at most (Fig. 2), and that in zircon ranges below $900 \mathrm{ppm}$ (Fig. 3). This observation leads us to the conclusion that radiation damage in our samples is unlikely to have had a major effect on ages and/or $\mathrm{T}_{\mathrm{c}}$, considering from He diffusion changing for slow cooling samples in Fig. 3 in Ault et al. (2019). Regarding AHe ages (Fig. 2, Table 1), most of the samples reproduced well; whereas, FST04 had the wide age dispersions. While, in ZHe ages (Fig. 3, Table 2), the grain ages for samples FST06 and 10 were grouped into two clusters. Age dispersion of $\mathrm{AHe}$ of FST04 within the error range of $\pm 3 \sigma$ in such localities has no correlation with eU, suggesting the little influence of radiation damage on these grain ages. On the other hand, only ZHe grain ages in FST10 appear to show a negative correlation within $\pm 3 \sigma$ against the $\mathrm{eU}$ values (Fig. 3). However, these samples indicate improbable effects to cause age dispersion or clustering from radiation damage, inferring age dispersion arises from other possible factors, such as zonation of parent nuclides (e.g., Meesters and Dunai 2002), implantation from neighbor minerals (e.g., Spiegel et al. 2009), and fluid inclusions of radiometric He traps (Daniš́k et al. 2017). Thus, we did not employ weighted mean ages for these three samples.

\section{Results of weighted mean ages}

Weighted mean ages for AHe data at nine localities and for $\mathrm{ZHe}$ data at five localities were obtained (Table 3). The weighted mean ages that we adopted for AHe range

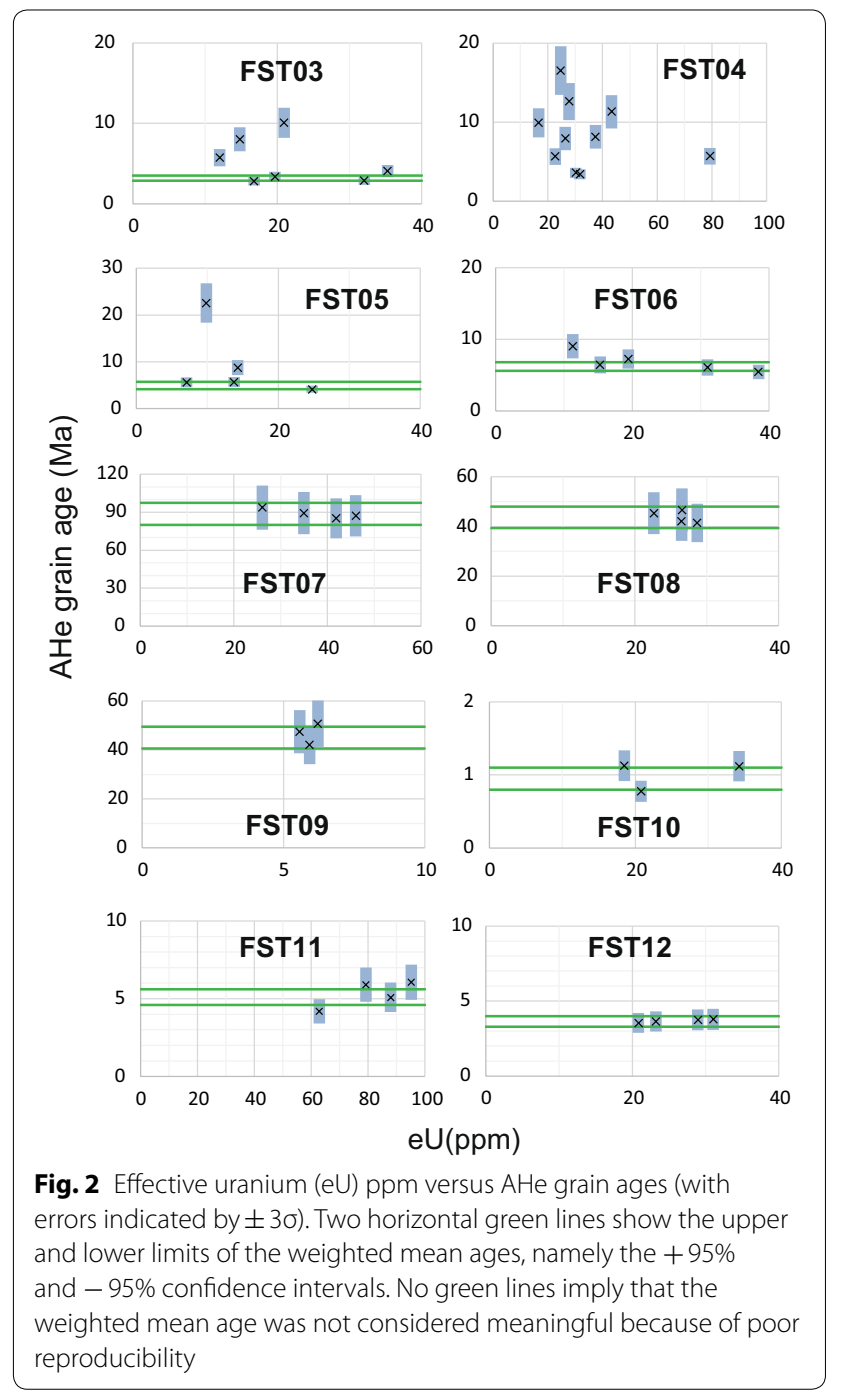

from 88.6 to $0.9 \mathrm{Ma}$ (Tables 1 and 3, Fig. 4c); while those for ZHe ages range from 83.9 to $9.9 \mathrm{Ma}$ (Tables 2 and 3, Fig. 4c). Fitzgerald et al. (2006) suggested that the true ages should be between weighted mean ages and minimum ages. We plotted the minimum ages for poorly reproduced samples together with the arithmetic mean ages (Fig. 4). In this figure, the mean AHe age of FST04, and $\mathrm{ZHe}$ ages of FST06 and 10 were displayed in gray color just for reference, although they have less reliable data than the others.

AHe ages are younger than or comparable to the corresponding $\mathrm{ZHe}$ ages considering the uncertainty of $95 \%$ confidence intervals. These results are consistent because of an expected age relationship resulting from the range of closure temperatures between the two systems. Moreover, two thermochronologic studies were previously conducted in this study area; AFT ages of 100.0-82.4 Ma and zircon FT (ZFT) ages of 93.4-90.1 Ma (Goto 2001) 

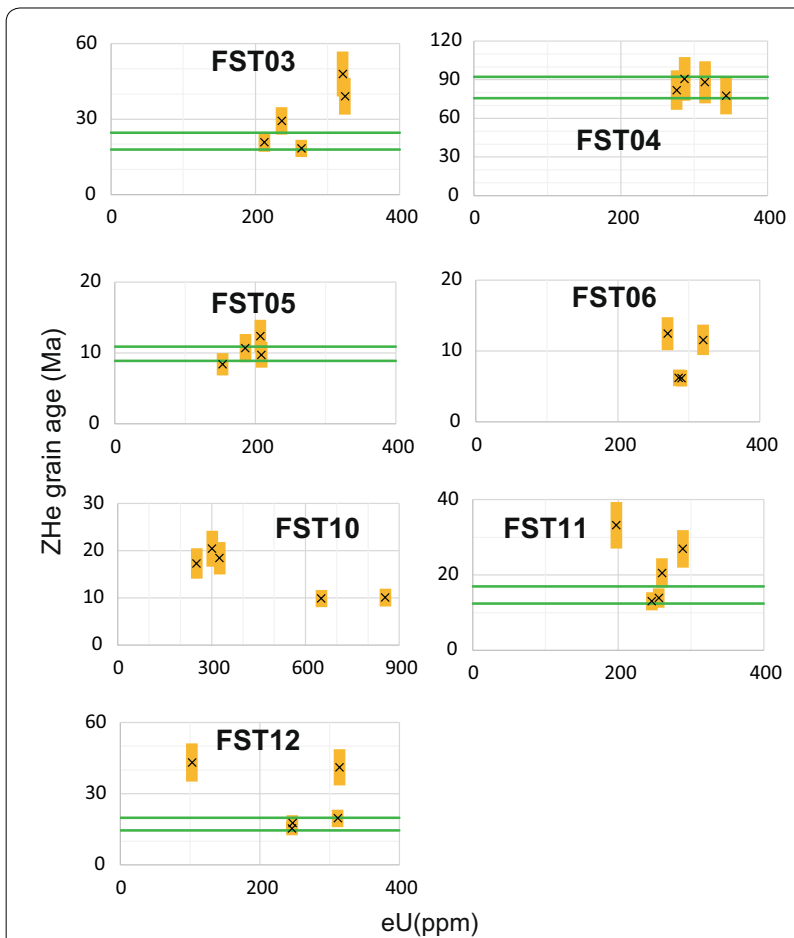

Fig. 3 Effective uranium (eU) ppm versus ZHe grain ages. Every grain range of age indicates $\pm 3 \sigma$ range. Two horizontal green lines show the upper and lower limits of the weighted mean age, namely $+95 \%$ and $-95 \%$ confidence intervals. No green lines imply that the weighted mean age is unadopted because of poor reproducibility

on the fore-arc side, and ZFT ages of 53.4-21.8 Ma (Ganzawa 1987) on the back-arc side (Fig. 1a). Results of our He dating show reasonable age relationships compared to these data.

As to the AHe ages in Fig. 4c, older ages range from 88.6 to $43.7 \mathrm{Ma}$ on the fore-arc side (FST07, 08, 09), while younger ages range from 6.2 to $0.9 \mathrm{Ma}$ in the OBR (FST06, 10, 11, 12) and between 4.9 and $3.2 \mathrm{Ma}$ on the back-arc side (FST03, 05) These results indicate a strong age contrast between the fore-arc side and west of the OBR.

\section{Geological implications}

\section{Calculation and interpretation of denudation rates}

Little radiation damage effects were observed in our samples; thus, we interpret AHe ages as cooling ages reflecting thermal histories. The AHe closure temperature at every locality is applicable to interpret such thermal histories, except for one over-dispersed age sample (FST04) (Table 3). Thus, we computed the individual closure temperatures of the AHe system for each sample, based on the Dodson (1973) method for calculating denudation rates. The closure temperature, $T_{\mathrm{c}}$, varies depending on the cooling rate, $d T / d t$, in addition to the dimension of the diffusion domain (the mean half width of each sample was adopted in this study; Table 1), $a$;

$$
\begin{aligned}
& T_{c}=\frac{E_{\mathrm{a}}}{R \ln \left(\frac{A \tau D_{0}}{a^{2}}\right)}, \\
& \frac{\mathrm{d} T}{\mathrm{~d} t}=\frac{T_{c}-T_{s}}{t_{\mathrm{AHe}}}, \\
& \tau=-\frac{R T_{c}^{2}}{E_{\mathrm{a}} \mathrm{d} T / \mathrm{d} t},
\end{aligned}
$$

where $E_{\mathrm{a}}$ is the activation energy $(=151.46 \mathrm{~kJ} / \mathrm{mol}), R$ is the gas constant $(=8.314 \mathrm{~J} / \mathrm{K} \mathrm{mol}), A$ is the geometric factor (=55 for sphere), $\tau$ is the time constant, $D_{0}$ is the diffusivity at infinite temperature $\left(=50 \mathrm{~cm}^{2} / \mathrm{s}\right), T_{s}$ is the surface temperature $\left(=10{ }^{\circ} \mathrm{C}\right.$, every locality), $t_{\mathrm{AHe}}$ is the AHe age of the sample. The calculation of closure temperatures was performed by repeatedly substituting $\mathrm{d} T / \mathrm{d} t, \mathrm{\tau}$, and $T_{c}$ until a stable value of closure temperature was obtained (up to ten times). Errors of $T_{c}$ were propagated from those of AHe ages and grain sizes. The results of the calculation of closure temperatures are shown in Table 3. On the fore-arc side, lower temperatures at ca. 50-55 ${ }^{\circ} \mathrm{C}$ (FST07, 08, 09) were calculated. On the other hand, higher temperatures at ca. $60-80{ }^{\circ} \mathrm{C}$ were calculated at the OBR (FST06, 10, 11, 12) and on the back-arc side (FST03, 05). The obtained closure temperatures were used to estimate mean denudation rates through geologic timescale by the following equation:

$$
\frac{\mathrm{d} D}{\mathrm{~d} t}=\frac{\mathrm{d} T / \mathrm{d} t}{G},
$$

where $\mathrm{d} D / \mathrm{d} t$ indicates the mean denudation rate since $t_{\mathrm{AHe}}, G$ denotes the geothermal gradient.

In the NE Japan Arc, geothermal gradients vary drastically with locality and the values used were extracted from Tanaka et al. (2004) and GSJ (2009) as shown in Table 3. In this study, thermal gradients were assumed to be constant temporally because it is difficult to evaluate their temporal and spatial variations over one-ten million years. Values of geothermal gradients were adopted at $20-40{ }^{\circ} \mathrm{C} / \mathrm{km}$ on the fore-arc side, and $40-60{ }^{\circ} \mathrm{C} / \mathrm{km}$ at the OBR and on the back-arc side based on the database of Tanaka et al. (2004). Alternatively, geothermal gradients at every locality were read on the iso-geothermal gradient map drawn at intervals of $10{ }^{\circ} \mathrm{C} / \mathrm{km}$ published by GSJ (2009). In this calculation, we adopted averages between the upper and lower limits of contours from sampling localities were included. Their uncertainties were assigned by the contour interval. Errors of 


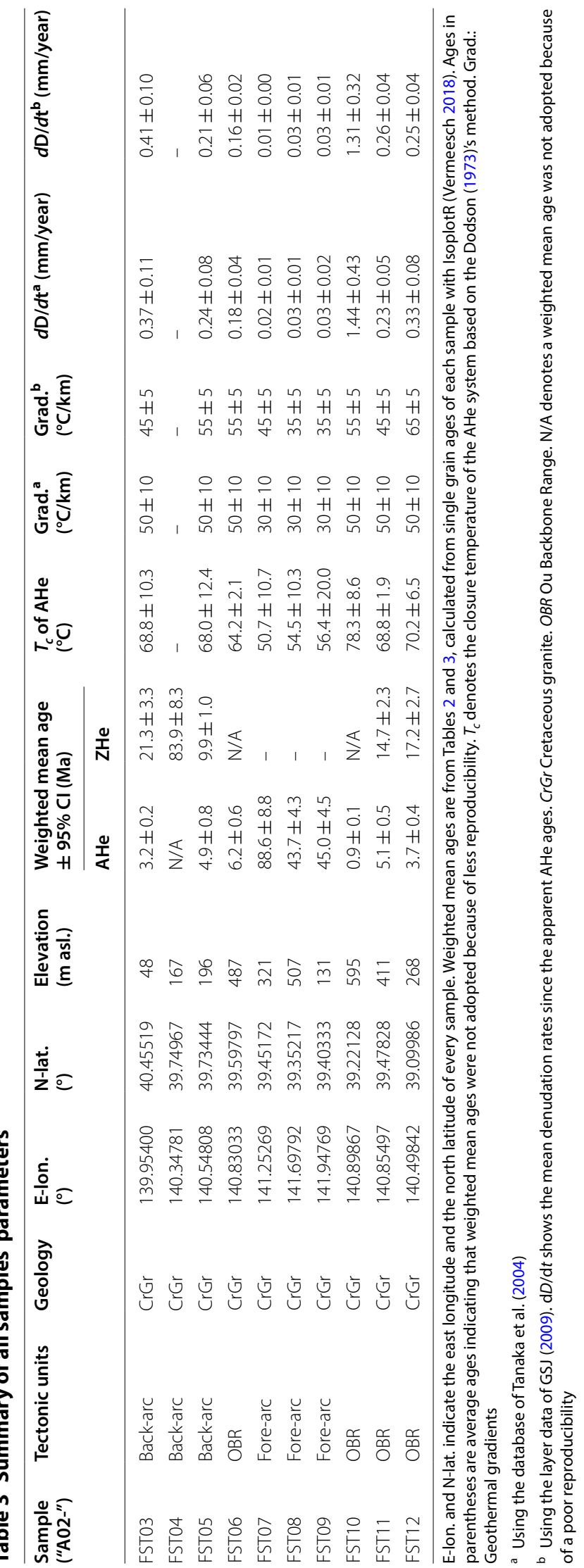




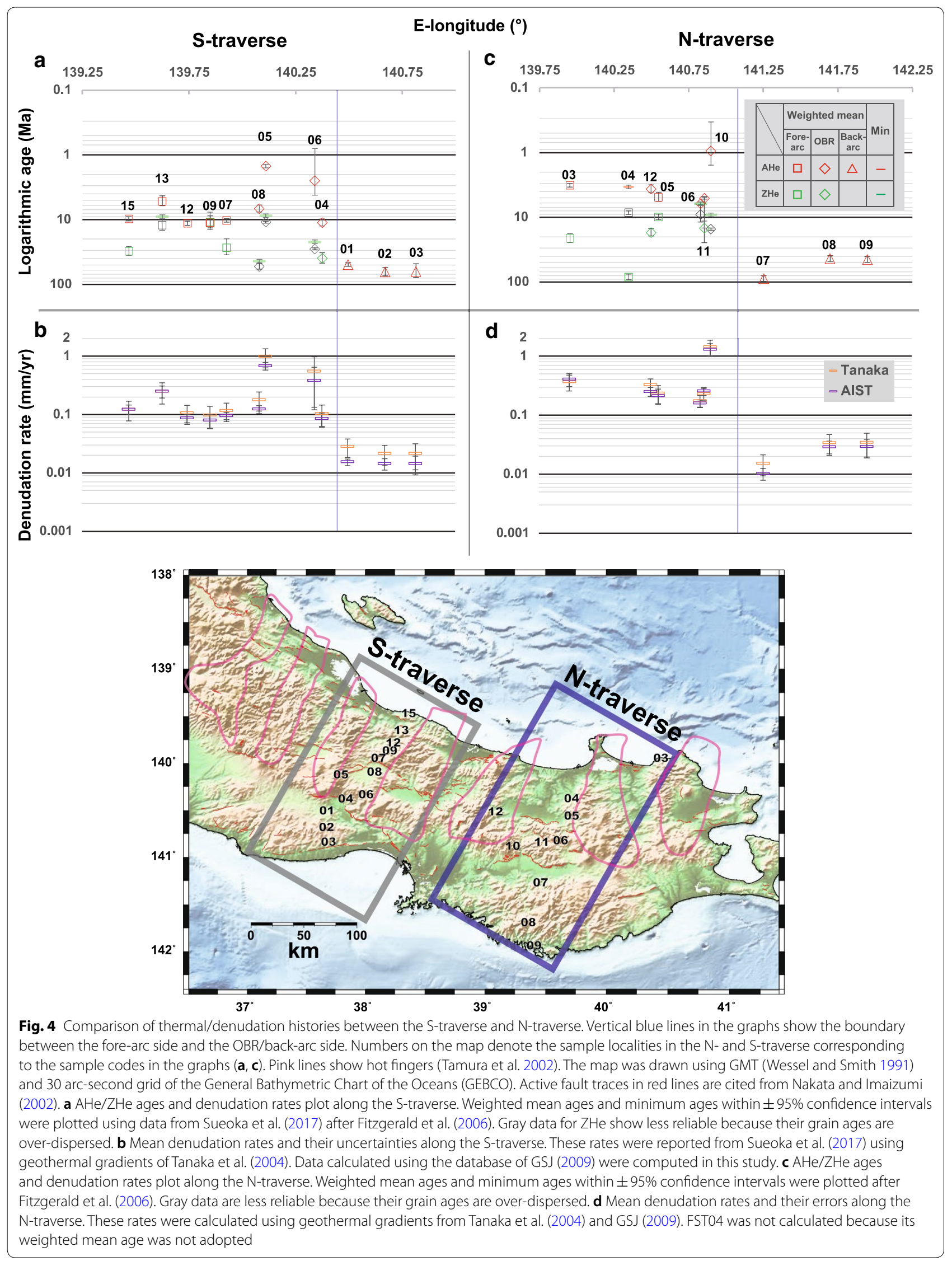


denudation rates were propagated from those of the ages, geothermal gradients, and grain sizes.

The computed denudation rates are shown in Table 3 and Fig. 4d. On the fore-arc side, slower rates at $<0.05 \mathrm{~mm} /$ year were calculated because of older $\mathrm{AHe}$ ages (FST07, 08, 09). Hence, AHe thermochronometers on the fore-arc side should indicate the mean denudation rates from Cretaceous, before the uplift of mountains. On the other hand, faster rates at $>0.1-1.5 \mathrm{~mm} /$ year were detected at the OBR and on the back-arc side. Such high denudation rates should be derived by a faster cooling rate calculated from closure temperatures $\left(60-80{ }^{\circ} \mathrm{C}\right)$ and younger $\mathrm{AHe}$ ages $(6-1 \mathrm{Ma})$. Consequently, a clear contrast in denudation rates is identified between the forearc side and the west of the OBR. In particular, younger AHe ages at 3-1 Ma (FST03, 10, 12) should have been affected by the strong E-W compression since 3-2 Ma. AHe ages $\sim 6-5 \mathrm{Ma}(\mathrm{FST} 05,06,11)$ have also affected but only partial age resetting is considered to have occurred under such compression since $\sim 3-2 \mathrm{Ma}$. As to other possibilities for explaining the young ages, Quaternary volcanisms or recent local heating was also considered to explain the younger AHe ages. Although we managed to eliminate thermal disturbances from major Quaternary volcanism as possibilities for age resetting, it is difficult to reject these possibilities completely because the $\mathrm{NE}$ Japan Arc has a complex tectonic history. However, we consider that AHe ages at $\sim 6-5 \mathrm{Ma}$ and their calculated denudation rates should be adopted as the upper limit of denudation rates.

In calculating the denudation rates, we assumed the linear and horizontal isotherms. However, isotherms should be perturbed by some factors during mountain building process, for instance, the amplitude of surface topography, the faster uplift/denudation, the ancientry of mountain, and so on (Stüwe et al. 1994). These factors can potentially cause an erroneous calculation of denudation rates. We did not consider these effects because (a) the mountains in the study area generally have moderate widths of ca. $40-80 \mathrm{~km}$ and lower elevations ranging from a few hundred to $\sim 1500 \mathrm{~m}$, (b) we obtained slower denudation rates of $0.01-1.5 \mathrm{~mm} /$ year, and (c) the onset of uplift of mountains has initiated since the last few Ma. We, thus, regarded them as negligible effects on isotherm advection according to these backgrounds in this study.

\section{Comparison of shorter-term denudation/uplift rates along the $\mathrm{N}$-traverse}

For creating current topographic landforms, the surface materials are subjected to vertical movements. As geomorphic fundamental, the relationships between uplift and denudation can simply be expressed as the following equation (England and Molnar 1990);
Surface uplift $=$ Bedrock uplift - exhumation (denudation).

Bedrock uplift is caused by tectonic and isostatic displacement/deformation, while exhumation (denudation) occurs as a result of tectonic denudation (e.g., normal faulting, crustal thinning), as well as erosion and weathering. Hence, bedrock uplift and denudation are independent processes even though they can interact with each other. In perspective, denudation should become faster as bedrock uplift increases, because topographic reliefs and slopes grow accompanied by bedrock uplift. However, bedrock uplift and denudation reach steady state, and then topographic reliefs do not change through time, a situation termed dynamic equilibrium (e.g., Ohmori 1985).

Shorter-term $\left(<\sim 10^{5}\right.$ year $)$ denudation rates have been obtained in the $\mathrm{N}$-traverse based on geomorphic and geologic approaches. As an overall trend, uplift and denudation rates on the shorter-term along the $\mathrm{N}$-traverse range from $\sim 0.1$ to $1.0 \mathrm{~mm} /$ year. A comparison between short- and long-term denudation/uplift rates is discussed separately in the three tectonic units described below. Furthermore, geodynamic modeling were concerned using a finite element method based on rheology for the entire NE Japan Arc (e.g., Shibazaki et al. 2008, 2016). Shibazaki et al. (2016), provide an estimate of long-term uplift rates assuming some boundary conditions and geophysical parameters. We also compared our denudation rates from thermochronometric data with those modeling results.

\section{Fore-arc side}

Denudation rates of $\sim 0.3-0.4 \mathrm{~mm} /$ year over $\sim 10^{1}$ year were calculated based on the amount of sedimentary loads in catchments (Fujiwara et al. 1999). Uplift rates were estimated at $\sim 0.2$ to $\sim 0.4 \mathrm{~mm} /$ year over $\sim 10^{5}$ year based on the elevations and emergent ages of the fluvial/ marine terraces (e.g., Tajikara and Ikeda 2005; Okuno et al. 2014). Moreover, geodynamic modeling, using the finite element method (Shibazaki et al. 2016), provided uplift rates up to $0.4 \mathrm{~mm} /$ year on a $10^{6}$ years timescale. Denudation rates at $<0.05 \mathrm{~mm} /$ year were obtained based on our thermochronometric data, indicating one order of magnitude discrepancy in rates between short- and long term (described later).

\section{Ou Backbone range}

Denudation rates of $0.3-0.4 \mathrm{~mm} /$ year over $\sim 10^{1}$ year were calculated based on the amount of sedimentary loads in catchments (Fujiwara et al. 1999). Uplift rates at $<0.6 \mathrm{~mm} /$ year were obtained over $\sim 10^{5}$ year based on the elevations and emergent ages of the fluvial/marine terraces (e.g., Tajikara and Ikeda 2005), and uplift rates of $\sim 0.5-0.7 \mathrm{~mm} /$ 
year from displacements across the eastern margin faults of Kitakami lowland and the western margin faults of Yokote basin on $10^{5-6}$ years timescales (Awata 1988; Ikeda et al. 2002; Doke et al. 2012). Geodynamic modeling using the finite element method (Shibazaki et al. 2016) offered uplift rates of $\sim 0.4-1.0 \mathrm{~mm} /$ year on a $10^{6}$ years timescale. Our denudation rates in this study were estimated at $\sim 0.2-1.4 \mathrm{~mm} /$ year, which are consistent with the independently derived short-term rates outlined above.

\section{Back-arc side}

Denudation rates at $\sim 0.4-0.5 \mathrm{~mm} /$ year over $\sim 10^{1}$ year were calculated based on the amount of sedimentary loads in catchments (Fujiwara et al. 1999). Uplift rates at $<0.6 \mathrm{~mm}$ /year were estimated over $\sim 10^{5}$ year based on the elevations and emergent ages of the fluvial/marine terraces (e.g., Tajikara and Ikeda 2005; Okuno et al. 2014), and uplift rates at $\sim 1 \mathrm{~mm} /$ year from displacements across Kitayuri faults at $10^{5-6}$ years timescales (Awata 1988; Doke et al. 2012). Uplift rates of $\sim 0.4-0.6 \mathrm{~mm} /$ year were based on geodynamic modeling using the finite element method on a $10^{6}$-year timescale (Shibazaki et al. 2016). Denudation rates at 0.1-0.4 were obtained based on thermochronometric data, which are consistent with other methods for the short term.

On the fore-arc side, the data between $10^{6-7}$ years from thermochronometry and $<10^{5}$ year from other methods have one order of discrepancy. This disagreement can be explained by considering the small amount of uplift/denudation compared to the closure temperature depth of the AHe system (typically ca. $>1-2 \mathrm{~km}$ ), even though the uplift of the fore-arc side has accelerated since the Quaternary (Ota et al. 2010). Hence, higher denudation/uplift rates should be detected in shorter-term $\left(<10^{5}\right.$ year $)$ methods. Besides, the total amount of denudation since the Quaternary is thought to be smaller than the closure depth of AHe system. This scenario is also supported by geomorphic evidence; the Kitakami Mountains have lowrelief erosional surfaces regarded as remnants of uplifted peneplains (Nakamura 1963). Namely, following the onset of uplift, the Kitakami Mountains have experienced such a relatively small degree of denudation that the erosional surfaces formed pre-uplift are still preserved. For verifying this explanation, the application of lower-temperature thermochronometers and terrestrial cosmogenic nuclides (TCN) method is desirable.

In contrast, denudation rates from thermochronometers on the $10^{6}$ years timescale are consistent with on the shorter-term $\left(<10^{5}\right.$ years $)$ denudation/uplift rates for the OBR and on the back-arc side. This observation implies that the regional denudation/uplift rates have been maintained under the E-W compression stress field since the Quaternary.
By comparing our thermochronometric data with geodynamic modeling results, the measured and modeled data indicated are consistent with each other on geologic timescales. Shibazaki et al. (2016) suggested such high uplift rates along the OBR, particularly in the regions of hot fingers, correspond to high-temperature zones, implying that heterogeneous thermal structures strongly control uplift of the OBR under a compressional stress field. Based on our thermochronology results, we obtained faster denudation rates; however, it is noted that we did not collect samples from within these hightemperature zones (Fig. 4). Hence, the uplift mechanism cannot necessarily be attributed to heterogeneous temperature distributions. Further, thermochronometric investigations or parameter tunings are required to elucidate the uplift mechanism.

\section{Comparison of thermal and denudation histories between the $\mathrm{N}$ - and S-traverses}

Our thermochronometric results indicate an obvious contrast in thermal/denudation histories between each tectonic unit along the $\mathrm{N}$-traverse. A similar contrast was also reported along the S-traverse (Sueoka et al. 2017; Fukuda et al. 2019). Integrating the results of both traverses, arc-parallel mountains in the NE Japan Arc indicate that they generally share a common thermal/ denudation history (Fig. 4). If the formation of topography in an island-arc setting is mainly caused by the subduction of an oceanic plate, then it would be possible for thermal histories of arc-parallel topographies to share common geologic features. This study has demonstrated that from two across-arc traverses, there are common thermal/denudation histories in an arc-parallel direction. Thermal/denudation histories in each tectonic unit are now compared and discussed.

\section{Fore-arc side}

Denudation rates are approximately in the same range; these rates along with the $\mathrm{N}$-traverse were estimated at $\sim 0.01-0.03 \mathrm{~mm} /$ year (Fig. $4 \mathrm{~d}$ ), and data for the S-traverse were $\sim 0.02-0.03 \mathrm{~mm} /$ year (Fig. 4b). However, the elevation of mountains and the formation age of granites are different; the Kitakami Mountains comprise $120-110$ Ma granites $>1200 \mathrm{~m}$ in elevation in the $\mathrm{N}$-traverse; while the Abukuma Mountains consist of 110-100 Ma granites with elevations of $<600 \mathrm{~m}$ in the $\mathrm{S}$-traverse. Differences in the geomorphic and geologic features between two traverses cannot be explained from thermochronologic data, as inferred total denudation and uplift since the Quaternary should be low as discussed in "Comparison of shorter-term denudation/ uplift rates along the $\mathrm{N}$-traverse" section. 


\section{Ou backbone range}

Denudation rates in the $\mathrm{N}$-traverse are slightly higher $(0.2-1.5 \mathrm{~mm} /$ year: Fig. $4 \mathrm{~d})$ than those in the S-traverse (0.1-1.0 mm/year: Fig. $4 \mathrm{~b})$. The elevation and distribution of faults are provided as examples of topographic differences between both traverses. The mean elevation of the OBR along the N-traverse (Fig. 1b) is a little lower than the S-traverse (see Fig. 1b in Sueoka et al. 2017). Moreover, the northern OBR has clear reverse faults along the foot of the mountains, whilst fault traces in the southern OBR are indeterminable near our sampling sites in both traverses. Considering the distribution of the last cooling episodes and denudation rates determined by AFT thermochronology along the S-traverse, Fukuda et al. (2019) implied that an uplift model for the OBR is probably by doming (Hasegawa et al. 2005) and not a tilted pop-up style by reverse faults (Nakajima 2013). Sueoka et al. (2015, 2016) showed that numerical modeling of slope development can also provide the pattern of denudation rate using the advection diffusion equation (e.g., Hirano 1972). Modeling results illustrated that the denudation pattern of doming model should increase towards the summit, but on the other hand, the tilted pop-up model should increase towards the foot of a mountain. Despite the OBR of N-traverse having obvious reverse faults, denudation rates from our AHe data (from FST06 to 11, and 10) indicate faster rates toward the summit of the OBR (Fig. 4c), thus supporting the doming uplift model. Although FST12 is here also included in the classification as the OBR, its denudation shows a little higher rate than for FST06. The locality of FST12 is around or on the boundary between the OBR and the back-arc side, and was, thus, perhaps also affected by the tectonics of the back-arc side, the Hinotodake mountains.

\section{Back-arc side}

There are two differences between both traverses; (a) maximum denudation rates in the $\mathrm{N}$-traverse $(0.1-$ $0.4 \mathrm{~mm} /$ year: Fig. $4 \mathrm{~d}$ ) are higher than for the S-traverse (0.1-0.25 mm/year: Fig. $4 \mathrm{~b})$, and (b) ZHe ages ranging over 80-10 Ma were obtained in the N-traverse (Fig. 4c), while those in the S-traverse ranged over 30-10 Ma (Fig. 4a). One of the fundamental causes of (a) is due to temporal variations in the initiation of uplift on the backarc side. Mountains in the Dewa hills have been uplifted non-simultaneously from $\sim 5$ to $3 \mathrm{Ma}$ (Moriya et al. 2008). Another cause is differences in elevation; the Iide and Asahi Mountains in the S-traverse have high elevations at $>2000 \mathrm{~m}$, while the Shirakami and Taihe Mountains are at an elevation $<1500 \mathrm{~m}$. These observations can be explained as follows: denudation rates for these mountains were almost in the same range, but the timing of initiation of uplift was not simultaneous as suggested by Moriya et al. (2008). The Iide/Asahi and Shirakami/Taihe Mountains, thus, have different present-day elevations. Although the long-term uplift rates or the timing of initiation of uplift on the back-arc side are poorly understood, AHe ages and denudation rates reflect recent tectonics after a few Ma. In the S-traverse, Fukuda et al. (2019) suggested that denudation rates on the back-arc side indicated different values between thermal inverse modeling of AFT method and previous AHe data (Sueoka et al. 2017). Modeling results offered more precise and faster denudation rates of $>1 \mathrm{~mm} /$ year (Fukuda et al. 2019), while such rates based on apparent $\mathrm{AHe}$ data indicated 0.1-0.3 mm/year (Fig. 4b). Similar approaches employing thermal inverse modeling based on AFT data are desirable for also the N-profile. Next, moving on to (b), the timing of formation of granites is different; all granites in the $\mathrm{N}$-traverse were formed in the Cretaceous around 120 $100 \mathrm{Ma}$, whilst some granites on the back-arc side of the S-traverse are Cretaceous-Paleogene (100-60 Ma) (e.g., Yokoyama et al. 2016). Another possible explaination for the different $\mathrm{ZHe}$ ages between the two traverses is that the amount of subsidence in both traverses should be different during the time of the Sea of Japan opening. Okada and Ikeda (2012) suggested that based on seismic reflection data, the amount of extension and contraction since the Miocene varied from $\sim 10$ to $60 \mathrm{~km}$ even in the backarc side. This variation of subsidence during the opening of the Japan Sea probably affects the different ZHe ages between two traverses.

In summary, the back-arc side has wide tectonic, geologic and topographic variation even within a single arc. These observations imply that arc-along tectonics are probably dominant, such as concentration of deformation around the high-temperature zones, namely hot fingers (Tamura et al. 2002). E-W mountain building on the back-arc side should have, thus, occurred under an N-S component of compressive stress (Fukahata 2016). Meanwhile, across-arc tectonics, such as the E-W compression derived from the oceanic plate subduction, does not prevail on the back-arc side, unlike in the OBR.

\section{Conclusions}

Apatite and zircon (U-Th)/He thermochronometric mapping across the northern NE Japan Arc, provides new insights into the tectonic history and the process of mountain building. Moreover, we compared thermochronometric data for the $\mathrm{N}$-traverse produced in this study and that previously published for the S-traverse to evaluate the trends in the thermal/denudation histories across an island arc. Consequently, we verified the contrast of thermal/denudation histories in the $\mathrm{N}$-traverse as well as the previous studies of S-traverse, which implied 
these findings indicate universal features along the NE Japan Arc. In contrast, some minor differences such as ages and denudation rates between both traverses were detected. These observations probably reflect the different geological and topographic backgrounds, and also tectonics before and after the opening of the Sea of Japan.

1. On the fore-arc side, slower denudation rates at $<0.05 \mathrm{~mm}$ /year were obtained, from which it is inferred that near-stable denudation has been dominant through Paleogene at the $\mathrm{N}$-traverse. Acceleration of uplift/denudation after the late Quaternary was also deduced by comparison of shorter- and longer-term trends. Similar thermal/denudation histories can be found between both traverses.

2. At the OBR, faster denudation rates at $\sim 0.2-1.5 \mathrm{~mm} /$ year were obtained, probably reflecting rapid cooling derived from recent uplift events since the Quaternary. The style of uplift of the OBR is probably most compatible with a doming uplift model and this is supported by thermochronometric data from the Nand S-traverses. Further research, i.e., denser thermochronometric mapping, is required to constrain the uplift model of mountains more precisely.

3 . On the back-arc side, denudation rates at $\sim 0.1-$ $0.4 \mathrm{~mm} /$ year were estimated along the $\mathrm{N}$-traverse, indicating faster rates than determined from the S-traverse (0.1-0.25 $\mathrm{mm} /$ year). A comparison between both traverses probably suggests that the thermal/denudation histories of the back-arc side have wide variation reflecting their different tectonic, geologic and topographic histories. In addition, on the back-arc side, arc-long tectonics is possibly dominant rather than across-arc tectonics.

\section{Abbreviations}

AFT: Apatite fission track; ZFT: Zircon fission track; AHe: Apatite (U-Th-Sm)/He; ZHe: Zircon (U-Th)/He; NE Japan Arc: Northeast Japan Arc; OBR: Ou Backbone Range.

\section{Acknowledgements}

Mineral separations were performed at Kyoto Fission-Track Co., Ltd. by Drs. T. Danhara and H. Iwano. Abaz Alimanović provided technical assistance with $(\mathrm{U}-\mathrm{Th}) / \mathrm{He}$ analyses. We appreciate the constructive comments of two anonymous reviewers which helped to improve the manuscript.

\section{Authors' contributions}

SF drafted the manuscript. SF, SS, and TT are responsible for the project, conducting research planning, sampling, and data interpretation. BK performed the $(\mathrm{U}-\mathrm{Th}) / \mathrm{He}$ analyses, assisted in drafting the manuscript and provided some editorial oversight. All authors read and approved the final manuscript.

\section{Funding}

This study was supported by the Grant-in-Aid for Scientific Research on Innovative Areas (KAKENHI No. 26109003, representative: Takeshi Sagiya) and by the Grant-in-Aid for Scientific Research (B) (KAKENHI No. 15H03736, representative: Takahiro Tagami) from the Ministry of Education, Culture, Sports, Science and Technology (MEXT), Japan. The University of Melbourne thermochronology laboratory receives support under the AuScope program of the National Collaborative Research Infrastructure Strategy (NCRIS).

\section{Availability of data}

The datasets generated during and/or analyzed during the current study are available from the corresponding author on reasonable request.

\section{Competing interests}

The authors declare that they have no competing interests.

\section{Author details}

1 Department of Geology and Mineralogy, Division of Earth and Planetary Sciences, Graduate School of Science, Kyoto University, Kyoto 606-8502, Japan.

${ }^{2}$ Tono Geoscience Center, Japan Atomic Energy Agency, Gifu 509-5102, Japan.

${ }^{3}$ School of Earth Sciences, University of Melbourne, Melbourne VIC3010, Australia.

Received: 29 September 2019 Accepted: 11 February 2020

Published online: 27 February 2020

\section{References}

Anderson AJ, Hodges KV, van Soest MC (2017) Empirical constraints on the effects of radiation damage on helium diffusion in zircon. Geochim Cosmochim Acta 218:308-322. https://doi.org/10.1016/j.gca.2017.09.006

Ault AK, Gautheron C, King GE (2019) Innovations in (U-Th)/He, fission-track, and trapped-charge thermochronometry with applications to earthquakes, weathering, surface-mantle connections, and the growth and decay of mountains. Tectonics 38:1-35. https://doi.org/10.1029/2018T C005312

Awata Y (1988) The shortening at inner belt of the middle northeast arc the mortion of the Pacific plate. Chikyu Monthly 10:587-591. http://ci.nii. ac.jp/naid/10003542550/ja/

Blythe AE, Burbank DW, Carter A, Schmidt K, Putkonen J (2007) Plio-Quaternary exhumation history of the central Nepalese Himalaya: 1. Apatite and zircon fission track and apatite [U-Th]/He analyses. Tectonics 26:VC3002. https://doi.org/10.1029/2006TC001990

Brown RW, Beucher R, Roper S, Persano C, Stuart F, Fitzgerald PG (2013) Natural age dispersion arising from the analysis of broken crystals. Part I: theoretical basis and implications for the apatite $(\mathrm{U}-\mathrm{Th}) / \mathrm{He}$ thermochronometer. Geochim Cosmochim Acta 122:478-497. https://doi.org/10.1016/j. gca.2013.05.041

Burbank DW, Leland J, Fielding E, Anderson RS, Brozovic N, Reid MR, Duncan C (1996) Bedrock incision, rock uplift and threshold hill slopes in the northwestern Himalayas. Nature 379:505-510

Cherniak DJ (2019) Diffusion of helium in radiation-damaged zircon. Chem Geol 529:1-7. https://doi.org/10.1016/j.chemgeo.2019.119308

Committee for Catalog of Quaternary Volcanoes in Japan (1999) Catalog of quaternary volcanoes in Japan. The Volcanological Society of Japan, Tokyo

Danhara T, Iwano H, Kasuya M, Yamashita T, Sumii T (1992) The use of sodium polytungstate, a new nontoxic heavy liquid. Chishitsu News 455:31-36. https://www.gsj.jp/data/chishitsunews/92_07_03.pdf

Danišík M, Mcinnes BIA, Kirkland CL, McDonald BJ, Evans NJ, Becker T (2017) Seeing is believing: visualization of He distribution in zircon and implications for thermal history reconstruction on single crystals. Sci Adv 3:1-9

Dickinson WR, Seely DR (1979) Structure and stratigraphy of Forearc regions. AAPG Bulletin 63(1):2-31. https://doi.org/10.1306/C1EA55AD16C9-11D7-8645000102C1865D

Dodson MH (1973) Closure temperature in cooling geochronological and petrological systems. Contrib Miner Petrol 40(3):259-274. https://doi. org/10.1007/BF00373790

Doke R, Tanikawa S, Yasue K, Nakayasu A, Niizato T, Umeda K, Tanaka T (2012) Spatial patterns of initiation ages of active faulting in the Japanese Islands. Active Fault Res 37:1-15 
England P, Molnar P (1990) Surface uplift, uplift of rocks, and exhumation of rocks. Geology 18:1173-1177. https://doi.org/10.1130/00917613(1990)018<1173:SUUORA $>2.3 . C O ; 2$

Farley KA, Wolf RA, Silver LT (1996) The effects of long alpha-stopping distance on (U-Th)/He ages. Geochim Cosmochim Acta 60(21):4223-4229

Fitzgerald PG, Baldwin SL, Webb LE, Sullivan PBO (2006) Interpretation of (UTh)/He single grain ages from slowly cooled crustal terranes: a case study from the Transantarctic Mountains of southern Victoria Land. Chem Geol 225:91-120. https://doi.org/10.1016/j.chemgeo.2005.09.001

Flowers RM, Ketcham RA, Shuster DL, Farley KA (2009) Apatite (U-Th)/He thermochronometry using a radiation damage accumulation and annealing model. Geochim Cosmochim Acta 73(8):2347-2365. https:// doi.org/10.1016/j.gca.2009.01.015

Fujiwara O, Sanga T, Ohmori H (1999) Regional distribution of erosion rates over the Japanese Islands. JNC Technical Review 5(12):85-93

Fukahata Y (2016) On the causes of across-arc mountain ranges in the back-arc region of Tohoku arc: importance of north-south compression. JpGUAGU Joint Session Abstruct, SGC63-30

Fukuda S, Sueoka S, Hasebe N, Tamura A, Arai S, Tagami T (2019) Thermal history analysis of granitic rocks in an arc-trench system based on apatite fission-track thermochronology: a case study of the Northeast Japan Arc. J Asian Earth Sci X 1:1-9. https://doi.org/10.1016/j.jaesx.2019.100005

Gallagher K (2012) Transdimensional inverse thermal history modeling for quantitative thermochronology. J Geophys Res Solid Earth 117:1 16. https://doi.org/10.1029/2011JB008825

Ganzawa Y (1987) Fission track ages of volcanic rocks from Cretaceous to Tertiary in the inner belt of Northeast Japan -Okushiri Island, Oga Peninsula and Asahi Mountains-. J Geol Soc Jpn 93(6):387-401

Gastil RG, DeLISLE M, Morgan JR (1967) Some effects of progressive metamorphism on zircons. Geol Soc Am Bull 78:879-906

Gautheron C, Tassan-Got L, Barbarand J, Pagel M (2009) Effect of alphadamage annealing on apatite (U-Th)/He thermochronology. Chem Geol 266(3-4):157-170. https://doi.org/10.1016/j.chemgeo.2009.06.001

Geological Survey of Japan A (2009) Geothermal potential map in Japan. Digital Geoscience Map, GT-4. https://www.gsj.jp/Map/JP/geothermal _resources.htm

Ginster U, Reiners PW, Nasdala L, Chanmuang N (2019) Annealing kinetics of radiation damage in zircon. Geochim Cosmochim Acta 249:225-246. https://doi.org/10.1016/j.gca.2019.01.033

Gleadow AJW, Harrison M, Kohn B, Lugo-zazueta R, Phillips D (2015) The Fish Canyon Tuff: a new look at an old low-temperature thermochronology standard. Earth Planet Sci Lett 424:95-108. https://doi.org/10.1016/j.epsl.2015.05.003

Goto A (2001) Formation ages of elevated peneplains of the Japanese Islands - an approach from the fission-track dating. In: Grant-in-Aid for Scientific Research Report

Guenthner WR, Reiners PW, Ketcham RA, Nasdala L, Giester G (2013) Helium diffusion in natural zircon: radiation damage, anisotropy, and the interpretation of zircon (U-Th)/He thermochronology. Am J Sci 313(3):145198. https://doi.org/10.2475/03.2013.01

Hasegawa K, Wakamatsu K, Matsuoka M (2005) Mapping of potential erosion-rate evaluated from reservoir sedimentation in Japan. Jpn Soc Nat Disaster Sci 24(3):287-301

Herman F, Seward D, Valla PG, Carter A, Kohn B, Willett SD, Ehlers TA (2013) Worldwide acceleration of mountain erosion under a cooling climate. Nature 504(7480):423-426. https://doi.org/10.1038/nature12877

Hirano M (1972) Theory on graded slopes. Geogr Rev Jpn 45:703-715

House MA, Farley KA, Stockli D (2000) Helium chronometry of apatite and titanite using Nd-YAG laser heating. Earth Planet Sci Lett 183(3-4):365368. https://doi.org/10.1016/S0012-821X(00)00286-7

Ikeda Y, Imaizumi T, Togo M, Hirakawa K, Miyauchi T, Sato H (2002) Atlas of quaternary thrust faults in Japan. University of Tokyo Press, Tokyo

Johnson JE, Flowers RM, Baird GB, Mahan KH (2017) "Inverted" zircon and apatite $(U-T h) / H e$ dates from the Front Range, Colorado: high-damage zircon as a low-temperature $\left(<50^{\circ} \mathrm{C}\right)$ thermochronometer. Earth Planet Sci Lett 466:80-90. https://doi.org/10.1016/j.epsl.2017.03.002

Jolivet L, Tamaki K, Fournier M (1994) Japan Sea, opening history and mechanism: a synthesis. J Geophys Res 99(11):22237-22259

Ketcham RA (2005) Forward and inverse modeling of low-temperature thermochronometry data. Rev Mineral Geochem 58(1):275-314. https://doi. org/10.2138/rmg.2005.58.11
Koike K, Tamura T, Chinzei K, Miyagi T (2005) Regional Geomorphology of the Japanese Islands vol.3 Geomorphology of Tohoku Region. University of Tokyo Press, Tokyo

Mcdowell FW, Mcintosh WC, Farley KA (2005) A precise 40Ar-39Ar reference age for the Durango apatite (U-Th)/He and fission-track dating standard. Chem Geol 214:249-263. https://doi.org/10.1016/j.chemg eo.2004.10.002

Meesters AGCA, Dunai TJ (2002) Solving the production-diffusion equation for finite diffusion domains of various shapes Part II. Application to cases with a-ejection and nonhomogeneous distribution of the source. Chem Geol 186:57-73. https://doi.org/10.1016/S0009-2541(01)00422-3

Moriya S, Chinzei K, Nakajima T, Danhara T (2008) Uplift of the Dewa Hills recorded in the Pliocene paleogeographic change of the western Shinjo Basin, Yamagata Prefecture. J Geol Soc Japan 144(8):389-404. http://ci.nii.ac.jp/naid/130004594869

Nakajima T (2013) Late cenozoic tectonic events and intra-arc basin development in Northeast Japan. INTECH, 153-189

Nakajima T, Danhara T, Iwano H, Chinzei K (2006) Uplift of the Ou Backbone Range in Northeast Japan at around $10 \mathrm{Ma}$ and its implication for the tectonic evolution of the eastern margin of Asia. Palaeogeogr Palaeoclimatol Palaeoecol 241(1):28-48. https://doi.org/10.1016/j.palae 0.2006 .06 .009

Nakamura Y (1963) Base levels of erosion in the central part of Kitakami Mountainland. Sci Rep Tohoku Univ 7th Ser Geogr 32:61-70

Nakata T, Imaizumi T (2002) Digital active fault map of Japan. University of Tokyo Press, Tokyo, p 60

Ohmori H (1985) A comparison between the Davisian scheme development by concurrent tectonics and denudation. Bull Dep Geol 17:19-28

Okada S, Ikeda Y (2012) Quantifying crustal extension and shortening in the back-arc region of Northeast Japan. J Geophys Res 117(1):1-28. https:// doi.org/10.1029/2011JB008355

Okamura Y, Watanabe M, Morijiri R, Satoh M (1995) Rifting and basin inversion in the eastern margin of the Japan Sea. Island Arc 4:166-181. https://doi. org/10.1111/j.1440-1738.1995.tb00141.x.tb00141.x

Okuno J, Nakada M, Ishii M, Miura H (2014) Vertical tectonic crustal movements along the Japanese coastlines inferred from late Quaternary and recent relative sea-level changes. Quatern Sci Rev 91:42-61. https://doi. org/10.1016/j.quascirev.2014.03.010

Ota Y, Koike K, Chinzei K, Nogami M, Machida Y, Matsuda T (2010) Geomorphology of Japanese islands. University of Tokyo Press, Tokyo

Otofuji Y, Matsuda T, Nohda S (1985) Opening mode of the Japan Sea inferred from the palaeomagnetism of the Japan Arc. Nature 317(17):603-604

Phillips D, Matchan EL (2013) Ultra-high precision 40Ar/39Ar ages for Fish Canyon Tuff and Alder Creek Rhyolite sanidine: new dating standards required? Geochim Cosmochim Acta 121:229-239. https://doi. org/10.1016/.gca.2013.07.003

Recanati A, Gautheron C, Barbarand J, Missenard Y, Pinna-Jamme R, Tassan-Got L, Carter A, Douville É, Bordier L, Pagel M, Gallagher K (2017) Helium trapping in apatite damage: Insights from (U-Th-Sm)/He dating of different granitoid lithologies. Chem Geol 470:116-131. https://doi.org/10.1016/j. chemgeo.2017.09.002

Reiners PW, Brandon MT (2006) Using thermochronology to understand orogenic erosion. Annu Rev Earth Planet Sci 34(1):419-466. https://doi. org/10.1146/annurev.earth.34.031405.125202

Sato H (1994) The relationship between late Cenozoic tectonic events and stress field and basin development in northeast Japan stress. J Geophys Res 99(11):261-274

Shibazaki B, Garatani K, Iwasaki T, Tanaka A, lio Y (2008) Faulting processes controlled by the nonuniform thermal strucuture of the crust and uppermost mantle beneath the northeastern Japanese island arc. J Geophys Res Solid Earth 113(8):1-19. https://doi.org/10.1029/2007JB005361

Shibazaki B, Okada T, Muto J, Matsumoto T, Yoshida T, Yoshida K (2016) Heterogeneous stress state of island arc crust in northeastern Japan affected by hot mantle fingers. J Geophys Res Solid Earth 121:3099-3117. https://doi. org/10.1002/2015JB012664.Received

Shuster DL, Farley KA (2009) The influence of artificial radiation damage and thermal annealing on helium diffusion kinetics in apatite. Geochim Cosmochim Acta 73:183-196. https://doi.org/10.1016/j.gca.2008.10.013

Shuster DL, Flowers RM, Farley KA (2006) The influence of natural radiation damage on helium diffusion kinetics in apatite. Earth Planet Sci Lett 249:148-161. https://doi.org/10.1016/j.epsl.2006.07.028 
Spiegel C, Kohn B, Belton D, Berner Z, Gleadow A (2009) Apatite (U-Th-Sm)/ He thermochronology of rapidly cooled samples: the effect of He implantation. Earth Planet Sci Lett 285:105-114. https://doi.org/10.1016/j. epsl.2009.05.045

Stüwe K, White L, Brown R (1994) The influence of eroding topography on steady-state isotherms. Application to fission track analysis. Earth Planet Sci Lett 124:63-74

Sueoka S, Tsutsumi H, Tagami T (2015) Development of low-temperature thermochronology and its application to uplift and denudational history of Japanese mountains. Earth Sci 69:47-70

Sueoka S, Tsutsumi H, Tagami T (2016) New approach to resolve the amount of Quaternary uplift and associated denudation of the mountain ranges in the Japanese Islands. Geosci Front 7(2):197-210. https://doi.org/10.1016/j. gsf.2015.06.005

Sueoka S, Tagami T, Kohn BP (2017) First report of (U-Th)/He thermochronometric data across Northeast Japan Arc: implications for the long-term inelastic deformation. Earth Planets Space 69(79):1-18. https://doi. org/10.1186/s40623-017-0661-z

Tajikara M, Ikeda Y (2005) Vertical crustal movement and development of Basin and Range topography in the middle part of the Northeast Japan arc estimated from Fluvial/Marine Terrace Data. Quat Res 44:229-245. https:// doi.org/10.4116/jaqua.44.229

Takahashi M (2006) Tectonic boundary between Northeast and Southwest Japan Arcs during Japan Sea opening. J Geol Soc Jpn 112(1):14-32. https ://doi.org/10.5575/geosoc.112.14

Takahashi M (2017) The cause of the east-west contraction of Northeast Japan. Bull Geol Surv Jpn 68(4):155-161. https://doi.org/10.9795/bullg sj.68.155

Tamura Y, Tatsumi Y, Zhao D, Kido Y (2002) Hot fingers in the mantle wedge: new insights into magma genesis in subduction zones. Earth Planet Sci Lett 197:105-116

Tanaka A, Yamano M, Yano Y, Sasada M (2004) Geothermal gradient data in and around Japan. Digital Geoscience Map, DGM P-5(Geological Survey of Japan)

Umeda K, Komatsu R, Nakatsukasa N (1999) Geothermal structure based on temperature logging data of Boreholes in Japan. JNC Technical Review 2:29-36

Uyeda S (1982) Subduction zones: an introduction to comparative subductology. Tectonophysics 81(3-4):133-159. https://doi.org/10.1016/00401951(82)90126-3
Uyeda S (1983) Comparative subductology. Episodes 2:19-24

Vermeesch P (2018) IsoplotR: a free and open toolbox for geochronology. Geosci Front 9(5):1479-1493. https://doi.org/10.1016/j.gsf.2018.04.00

Vernon AJ, van der Beek PA, Sinclair HD, Rahn MK (2008) Increase in late Neogene de- nudation of the European Alps confirmed by anal-ysis of a fission-track thermochronology database. Earth Planet Sci Lett 270:316-329

Wagner GA, Reimer G, Jäger E (1977) Cooling ages derived by apatite fissiontrack, mica Rb-Sr and K-Ar dating; the uplift and cooling history of the Central Alps. Mem Inst Geol Miner Univ Padova 30:1-27

Wessel P, Smith WHF (1991) Free software helps map and display data. Eos Trans Am Geophys Union 72(41):441-448. https://doi.org/10.1029/90EO0 0319

Wildman M, Brown R, Beucher R, Persano C, Stuart F, Gallagher K, Carter A (2016) The chronology and tectonic style of landscape evolution along the elevated Atlantic continental margin of South Africa resolved by joint apatite fission track and (U-Th-Sm)/He thermochronology. Tectonics 35:511-545. https://doi.org/10.1002/2015TC004042.Received

Willett CD, Fox M, Shuster DL (2017) A helium-based model for the effects of radiation damage annealing on helium diffusion kinetics in apatite. Earth Planet Sci Lett 477:195-204. https://doi.org/10.1016/j.epsl.2017.07.047

Yokoyama K, Shigeoka M, Otomo Y, Tokuno K, Tsutsumi Y (2016) Uraninite and thorite ages of around 400 granitoids in the Japanese Islands. Memoirs Natl Mus Nat Sci 51:1-24

Yonekura N, Kaizuka S, Nogami M, Chinzei K (2001) Topology in Japan 1 review. University of Tokyo Press, Tokyo

Yoshida T, Kimura J, Yamada R, Acocella V, Sato H, Zhao D, Imaizumi T (2013) Evolution of late Cenozoic magmatism and the crust-mantle structure in the NE Japan Arc. Geol Soci London Spec Publ 385:335-387. https://doi. org/10.1144/SP385.15

\section{Publisher's Note}

Springer Nature remains neutral with regard to jurisdictional claims in published maps and institutional affiliations.

\section{Submit your manuscript to a SpringerOpen ${ }^{\circ}$ journal and benefit from:}

- Convenient online submission

- Rigorous peer review

- Open access: articles freely available online

- High visibility within the field

- Retaining the copyright to your article

Submit your next manuscript at $\boldsymbol{\nabla}$ springeropen.com 